\title{
GENDER DIFFERENCES IN JOB ABILITY PERCEPTION AND TASK PERFORMANCE AMONG PROFESSIONALS IN MALE DOMINATED PROFESSIONS
}

\author{
OSARENREN, Ngozi PhD \\ Associate Professor, \\ Department of Educational Foundations \\ University of Lagos, Akoka, Lagos. Nigeria \\ ngoziosarenren@yahoo.com
}

And

\author{
OGUNLEYE, Toluwalope PhD \\ Department of Counselling Psychology \\ Tai Solarin University of Education, Ijagun, Ogun State, Nigeria. \\ e-mail: toluwalopeogunleye@yahoo.com
}

\begin{abstract}
:
This study investigated gender differences in Job Ability Perception and Task Performance among professionals in male dominated professions. The study was a descriptive survey research design. Four professions from the male dominated professions were randomly selected from Lagos and Rivers States. A total of 800 professionals from the four male dominated professions namely: Engineering, Statistics, Medicine and Estate Management were selected using cluster random sampling technique. Two hypotheses were postulated and an instrument developed by the researchers (Ability/Performance Scale (APS) with a reliability value of $r=.78$ was used to collect relevant data to test the hypotheses. The data collected was analysed using students 't-test Statistical analysis. The findings of the study revealed that there was no significant difference in Job Ability Perception among professionals (both male and female) in male dominated professions; while, there was a significant gender difference in tasks given to the Engineers and Estate Managers but no significant gender difference in the tasks given to the Statisticians and Medical Doctors. The implications of these findings are exhaustively discussed.
\end{abstract}

Key words: Gender differences; Job ability perception; Task performance. 


\section{Introduction:}

Historically, women have been differently integrated into the social and economic systems of their various societies. Generally, women bear and raise children with minimal help in many parts of the world, Ogunleye (2006). Ogunleye (2006) also observed that women are responsible for growing and preparing the food the families eat and the maintenance of their children's health. Changes in the society brought about by new system of government, education, religion, economic, science and technology has increased women's participation in both private and public sectors. They now compete with men in almost every available job in the society even those that are considered exclusively male dominated. Male dominated professions are the Science, Technology and Mathematics related professions, (Graham 1997). Graham (1997) and Ogunleye (1998) even observed that women are still under represented in these professions.

According to Ellens (1994), disproportionate male-female ratios in some professions make it difficult for several women to interact well with their male colleagues. The reason for this, being that, men tend to see women who are in the same profession with them as rivals and not colleagues. This is due to the social orientation of the men to regard women as primarily home makers who are biologically different from men. As a result of this assumed biological difference women cannot therefore be competent or have ability to perform in the male dominated professions.

Due to the societal orientation of individuals, the type of tasks given to both male and female also differ. Tasks and chores are often assigned according to what parents perceive as gender appropriate, with boys more often assigned to outdoor tasks and girls more often assigned to inside tasks, (Rossenwasser, 1992). Expectations of parents for their children differ depending on their gender. Expectations, such as hard work, intelligence, honesty, ambitions, aggressiveness, independence and success have been reported for males while expectations such as good mother, good wife, kindness, loving and attractiveness have been reported for females (Hoffman, 1977).

These parental expectations may influence the occupations and roles children select for themselves, (Rosenwasser, 1982). Greenfield, Holloway and Remus (1982) found that men are motivated towards professions that deal with inanimate objects, e.g. engineering; while women are motivated towards professions that involve interaction with people, e.g. teaching and nursing. Women who, therefore, found 
themselves in male dominated professions which basically involve dealing with inanimate objects are given different tasks to perform which differ from what their jobs entails.

Nevil and Stecker (1988) found out that strong self-efficacy expectations and assertiveness were related to a willingness to engage in non-traditional career-related activities. Women in non-traditional careers therefore have higher self-efficacy for working with people when compared with women in the traditional professions, (Whiston, 1993).

\section{Statement of the Problem:}

Generally, women work in four career categories namely: Nursing, Teaching, Secretarial and Clerical positions (Foss and Stanley, 1986). Onwuchekwa (1990) confirmed this when she concluded that women in most cases engaged in some form of work which require mainly social and interpersonal skills. These stereotypically feminine occupations pay less income and have less status when compared to the non-traditional occupations like Engineering and Architecture. Few women have broken these barriers and have entered the male dominated professions, though they have not found it rosy. These women in the non-traditional professions are therefore held with suspect by the society in general. They belief that since they are in the "wrong" profession, they cannot be competent in handling what their job entails. This can lead to gender discrimination in job allocation where a female engineer for instance will be asked to stay behind in the office to attend to files and the male engineer is posted to the site to work. With this problem, the self-concept of the female professionals might be affected where they believe that they do not have enough ability to carry out their jobs when compared with their male counterparts.

\section{Purpose of the Study}

The purpose of the study is to:

Assess how women perceive their abilities to carry out their jobs when compared to their male counterparts.

Find out the difference in tasks performance among male and female professionals in male dominated professions.

\section{Hypotheses}

The hypotheses for the study are highlighted below:

1. There is a significant gender difference in Job Ability Perception among professionals in male dominated professions. 
2. There is a significant gender difference in Task Performance among the professionals in male dominated professions.

\section{Operational Definition of Terms:}

Traditional Professions: These are professions in which the majority of the professionals employed are females. Examples are: Teaching, Nursing, Secretarial and Clerical work.

Non-Traditional professions: They are that type of professions in which the membership is adjudged to be mostly male. Examples are Engineering, Medicine, and Estate Management.

\section{Methodology:}

The research design is a descriptive survey research design method. The target population for this study consisted of men and women in nontraditional professions from Lagos and Rivers State in Nigeria. Lagos is a state in the western part of Nigeria and Rivers State is from the southsouth region of Nigeria. The sample comprises of 400 male and 400 female professionals from four (4) male dominated professions. All the male dominated courses offered in Nigeria higher institution of learning were highlighted and using the "hat and draw" method, four professions were picked. The professions are Engineering, Medicine, Statistics and Estate Management. A stratified simple random sampling technique was used to get participants from the four male dominated professions in their various establishments. The instrument used for data collection was an instrument developed by the researcher. This is the Ability and Performance Scale. The questionnaire consisted of Two (2) parts: Part One measured the Job Ability Perception while Part Two measured Task Performance. Both parts had 16 items. The instrument has a test-retest reliability estimate of 0.78 .

\section{Result:}

To analyse the data, the students 't-test statistical analysis was used for the two hypotheses to test if any significant difference existed. This was done at 0.05 level of significance. 


\section{Hypothesis One:}

Table 1: t-test Gender Comparison of Job Ability Perception of Different Professionals

\begin{tabular}{|c|c|c|c|c|c|c|c|}
\hline \multirow{2}{*}{ Occupation } & \multicolumn{3}{|c|}{ Male } & \multicolumn{3}{|c|}{ Female } & \multirow{2}{*}{$\mathbf{t}_{\text {calculated }}$} \\
\hline & $\mathbf{N}$ & $\mathrm{X}$ & Sd & $\mathbf{N}$ & $X$ & Sd & \\
\hline Engineering & 203 & 41.05 & 5.47 & 203 & 41.75 & 5.12 & 1.89 \\
\hline Statistics & 47 & 40.41 & 6.28 & 47 & 41.0 & 5.87 & 0.67 \\
\hline Medicine & 112 & 41.59 & 6.62 & 112 & 41.88 & 6.73 & 0.46 \\
\hline $\begin{array}{l}\text { Estate } \\
\text { Management. }\end{array}$ & 38 & 41.37 & 6.26 & 38 & 41.56 & 5.54 & 0.20 \\
\hline
\end{tabular}

Table 1 shows that there is no significant difference in the Job Ability Perception of male and female professionals in engineering, since $(\mathrm{t}=1.89 ; \mathrm{P}<0.05 ; \mathrm{df}=404)$.

Also, it was found that male Statisticians do not differ in their Job Ability Perception from female Statisticians as the value of $(\mathrm{t}=0.67 ; \mathrm{P}<$ $0.05 ; \mathrm{df}=92)$. Similarly, the value of $(\mathrm{t}=0.46 ; \mathrm{P}<0.05)$. So, there is no significant gender difference in the Job Ability Perception among medical doctors.

The result also shows that there is no statistical difference in Job Ability Perception in male and female Estate Managers, since the value of $(\mathrm{t}=0.20 ; \mathrm{P}<0.05)$ is not significant. The hypothesis which states that there is a significant gender difference in job ability perception among the professionals is therefore rejected.

\section{Hypothesis Two:}

Table2: t- test Gender Comparison of Task Performance among the Professionals

\begin{tabular}{|l|c|c|c|c|c|c|l|l|l|}
\hline \multirow{2}{*}{ Occupation } & \multicolumn{3}{|c|}{ Male $\mathbf{n}=\mathbf{4 0 0}$} & \multicolumn{3}{|c|}{ Female $\mathbf{n}=\mathbf{4 0 0}$} & \multirow{2}{*}{ DF } & \multirow{2}{*}{$\mathbf{t}_{\text {cal }}$} & \multirow{2}{*}{$\mathbf{t}_{\text {crit }}$} \\
\cline { 2 - 11 } & $\mathrm{N}$ & $\mathbf{X}$ & $\mathbf{S D}$ & $\mathrm{N}$ & $\mathbf{X}$ & $\mathbf{S D}$ & & \\
\hline Engineering & 203 & 18.61 & 3.61 & 203 & 17.32 & 3.14 & 4.04 & $3.39^{*}$ & 1.96 \\
\hline Statistics & 47 & 17.65 & 4.11 & 47 & 17.24 & 3.73 & 92 & 0.5 & 1.98 \\
\hline Medicine & 112 & 18.38 & 3.82 & 112 & 18.29 & 4.08 & 222 & 0.17 & 1.96 \\
\hline $\begin{array}{l}\text { Estate } \\
\text { Management }\end{array}$ & 38 & 19.57 & 31.60 & 38 & 16.88 & 4.41 & 74 & $2.92^{*}$ & 1.98 \\
\hline
\end{tabular}


Table 2 shows that the value of $(\mathrm{t}-3.39 ; \mathrm{P}>0.05$; $\mathrm{df}=404)$. Therefore, there is a significant gender difference in task performance among the engineers. Also, there is a significant gender difference in the task performance between the male and female Estate Managers. This is because the $(\mathrm{t}=2.92 ; \mathrm{P}>0.05 ; \mathrm{df} 74)$. On the other hand, for the Statisticians, the value of $(\mathrm{t}=0.5 ; \mathrm{P}<0.05 ; \mathrm{df} 92)$ shows that no significant gender difference occurs in Task performance among the statisticians. Also, with the Medical Doctors the value of $(\mathrm{t}=0.17$; $\mathrm{P}<0.05$; df 222$)$ shows that no significant gender difference occurs in Task performance.

\section{Discussion}

The result of the analysis revealed that both the male and female professionals in the four non-traditional professions used for the study perceive the ability to carry out their jobs the same way, that is; they both have a high perception which shows a positive self concept. This seems to confirm the findings of Chusmir, (1983); and Letarte (1992). They maintained that women who have pursued non-traditional fields have reported higher levels of instrumental characteristics, while those in traditional fields have reported expressive characteristics. Instrumental characteristics include being goal-directed, task-oriented and independent. These traits are boosters to ones self-concept which probably explain why even the females in the non-traditional professions have a high job ability perception like their male counterparts. The findings are also in consonance with the findings of Nevil and Stecker (1988). They found that strong self efficacy expectations and assertiveness were related to a willingness to engage in non-traditional career-related activities. This therefore shows that the higher the job ability perception the higher the self concept.

The study also revealed a significant difference occurred in the type of task given to female Engineers and female Estate Managers when compared to their male counterparts. Kahn, (1990) gave credence to the findings when he maintained that boys and girls grow up having different play experiences. Pre-school boys handle more tools, throw more balls, construct more lego bridges, build more block towers, and handle simple mechanical objects than girls. This probably explains why these female professionals are given different tasks to perform. The societal orientation is that men are more skilful when dealing with inanimate objects hence the difference in play experiences when boys and girls are growing up. These experiences are carried to the field of work this explains the reason why men are asked to go to the field and work in 
professions like Engineering and Estate Management and the females stay behind to do "glorified secretarial work".

For the Medical Doctors and Statisticians, there was no significant difference in tasks performance among male and female professionals. Maccoby and Jacklin (1975) buttressed the findings on the medical doctors and statisticians as they stated that both sexes are motivated to achieve. But they are orientated towards different kinds of achievement. Boys are primarily interested in achieving on tasks that deals with inanimate objects or impersonal ideas and girls on tasks that involve interaction with people. Since medicine and statistics are professions that deal with interaction with people members of society do not find out of place.

\section{Conclusion:}

On the basis of the findings from this study it is concluded that:

- there is no significant difference in the job ability perception of male and female professionals in engineering ; statistics; medicine and estate management.

- there is a gender difference in tasks performance of professionals in engineering and estate management.

- there is no significant gender difference in tasks performance among professionals in statistics and medicine.

\section{Recommendation:}

Educational bodies such as the Ministry of Education (Both Federal and State) should ensure that career guidance is integrated in the everyday classroom activities through a developmental framework beginning from the primary school level. These career development and academic programmes should include teaching on professional equity for both girls and boys. In other words, students should be sensitized right from the primary schools to choose whatever professions they want as long as they have the ability and interest.

The career developmental programmes should continue well into the secondary school and should also include, at this stage, programmes that increase girls' self-esteem. Often times, self-esteem and Mathematics self-efficacy begin to increase at this age. Therefore, Mathematics and Science course work should be taught at this stage in an interesting way and also be full of activities in order to improve the girls' spatial abilities and boost their confidence and interest. 


\section{References:}

American Association of University Women (AAUW) (1992). How Schools Short-change Girls. Washington, D. C.

Chusmir, L. H. (1983), "Characteristics and Predictive Dimensions of Women Who Make Non-Traditional Vocational Choices". The Personnel and Guidance Journal, 62 (1), 43 - 47

Ellens, P. (1994). Social Acceptability Among Female Workers. An unpublished Ph. D. Thesis. Vagina Polytechnic institutes and State University , Virginia.

Graham, L. (1997) Profiles of Persistence, A Qualitative Study of Undergraduate Women in Engineering. An unpublished Ph. D. Thesis. Virginia Polytechnic Institutes and State University, Virginia.

Greenfield, L. B. Howoway, E. L., and Remus, L. (1982). "Women Students in Engineering, Area they are so different from men". Journal of College Student Personnel, 26(6), 508 - 514.

Hoffman, L. (1977). "Changes in Family Roles, Socialization and Sex Difference". American Psychologist, 32, 644 - 657.

Kahn, J. (1990). Why Girls Don't Know. In M. Rove (Ed), What Research says to the Science Teacher - The Process of Knowing. Washington, D. C: National Science Teachers Association.

Letearte, D. C. (1992). An Expression of Feminity; the Delimiting Role of Female Socialization in the Career Choice Process. Unpublished Masters Thesis, Southern Illinois University, Carbon dale, IL.

Maccoby, E. E. and Jacklin, C. N. (1975); The Psychology of Sex Differences. Stanford; Stanford University Press.

Mathieu, P. W., Sowa, C. J. and Niles, S. G. (1993). “Differences in Career Self-efficacy Among Women". Journal of Career Development, 19(3), $187-196$.

Nevil, D. D. \& Schlecker, D. L. (1988). “The Relation of Self-efficacy and Assertiveness to Willingness to engage in Traditional/Nontraditional Career Activities". Psychology of Women Quarterly, 12; $91-98$.

Ogunleye T. O. (2006) Success Anxiety, Job ability perception and social interaction among women in male dominated professions 'Implications for counselling'. An unpublished PhD Thesis, University of Lagos. Akoka, Lagos. 
Ogunleye, A. (1998) “Constraints to women and Girls' Participation in Science, Technology and Mathematics Education: The Way Forward". Women Education and Development, 1 (1), 9 - 20.

Onwuchekwa, N. (1990). Professional Aspiration and success Anxiety among female professional workers in Imo State. An unpublished PhD Thesis, University of Calabar, Calabar.

Rossen-Wasser, S. (1992). Differential Socialization Processes for Males and Females. Paper presented to the Texas Personnel and Guidance Association, Houston.

Whiston, S. C. (1993). "Self-efficacy of Women in Traditional and Nontraditional Occupations: Differences in working with people and things". Journal of Career Development 19, (3), 175 - 186. 